\title{
Two types of 16S rRNA gene are found in Campylobacter helveticus: analysis, applications and characterization of the intervening sequence found in some strains
}

\author{
Dennis Linton, ${ }^{1}$ Floyd E. Dewhirst, ${ }^{3}$ Jonathan P. Clewley, ${ }^{2}$ \\ Robert J. Owen, ${ }^{1}$ André P. Burnens ${ }^{4}$ and John Stanley ${ }^{1}$ \\ Author for correspondence: John Stanley. Tel: +44812004400 ext. 3738. Fax: +44812007874.
}

\begin{abstract}
1, 2 National Collection of Type Cultures ${ }^{1}$ and Virus Reference Division², Central Public Health Laboratory, 61 Colindale Avenue, London NW9 5HT, UK

3 Forsyth Dental Centre, Department of Molecular Genetics, 140 The Fenway, Boston, MA 02115, USA

4 Swiss National Reference Laboratory for Foodborne Diseases, Institute for Veterinary Bacteriology, University of Berne, Langass-Strasse 122, $\mathrm{CH}$ 3012 Berne, Switzerland
\end{abstract}

\begin{abstract}
In the recently described species Campylobacter helveticus, two sizes of PCR amplicon were detected with primers homologous to conserved regions of the 165 rRNA gene. A conventionally sized gene was sequenced from the type strain, NCTC 12470, placing the new species as phylogenetically related to $C$. upsaliensis and the thermotolerant campylobacters. This nucleotide sequence enabled PCR primers to be designed for use in rapid molecular identification of C. helveticus and its closest phylogenetic relative, $C$. upsaliensis. When this assay was employed to characterize 22 'C. upsaliensis-like' isolates, twelve were identified as $C$. helveticus and nine as $C$. upsaliensis, in agreement with data obtained with a C. helveticus-specific DNA probe. A 550 bp amplicon internal to the $16 \mathrm{~S}$ rRNA gene of $C$. he/veticus was used to determine restriction fragment length polymorphisms (RFLPs) in genomic Southern blots, confirming that the copy number of the $C$. helveticus gene was three, and identifying nine 165 rRNA gene profiles. In 5/12 C. helveticus isolates identified by PCR, an enlarged amplicon was detected. The enlarged 165 rRNA gene of one of these strains, NCTC 12838, was sequenced and shown to contain an atypical intervening sequence (IVS) of 148 nucleotides. The position and size of such an IVS was inferred in the other four isolates by PCR with primers $5^{\prime}$ and $3^{\prime}$ to its position in NCTC 12838. This is a first report of an IVS in the 16S rRNA gene of a eubacterium.
\end{abstract}

Keywords: Campylobacter belveticus, 16S rRNA gene, intervening sequence, phylogenetic analysis, molecular subtyping

\section{INTRODUCTION}

Campylobacter belveticus is a recently described member of the genus Campylobacter (Stanley et al., 1992) isolated from domestic cats. It is important to establish precise means for identification and subtyping of newly described Campylobacters in order to clarify their role in animal or human disease.

The gene encoding $16 \mathrm{~S}$ ribosomal RNA has been

\footnotetext{
Abbreviations: IVS, intervening sequence; RFLP, restriction fragment length polymorphism.

The GenBank accession number for the 165 RNA sequence of $C$. helveticus NCTC $12470^{\top}$ is $U 03022$.
}

sequenced from Escherichia coli and numerous other bacterial species. Its length is generally uniform, whilst variable regions within the gene have been employed to derive phylogenetic relationships between bacterial species (Woese, 1987).

In the study described here, by analysis of the nucleotide sequence of the conventionally sized $16 \mathrm{~S}$ rRNA gene found in the type strain of $C$. belveticus NCTC $12470^{\mathrm{T}}$, we have established the phylogenetic position of the species, designed a specific PCR-based identification method, and described a molecular subtyping scheme for isolates of this species. Certain strains of $C$. belveticus contain atypically large $16 \mathrm{~S}$ rRNA genes, and we have characterized the enlarged gene from one such strain, demonstrating the presence of an intervening sequence, whose 
Table 1. Bacterial strains

\begin{tabular}{|c|c|c|c|c|c|c|c|}
\hline \multirow[t]{2}{*}{ Strain } & \multirow[t]{2}{*}{ Reference $\ddagger$} & \multirow[t]{2}{*}{ Source } & \multirow[t]{2}{*}{$\begin{array}{l}\text { Selenite } \\
\text { reduction }\end{array}$} & \multirow[t]{2}{*}{$\underset{\text { hybridization }}{\mathrm{PCH1}}$} & \multicolumn{2}{|c|}{$\begin{array}{c}\text { PCR } \\
\text { identification }\end{array}$} & \multirow[t]{2}{*}{$\begin{array}{c}16 S \text { gene } \\
\text { profile }\end{array}$} \\
\hline & & & & & CHCUS & $\mathbf{C H} \|$ & \\
\hline \multicolumn{8}{|l|}{ Campylobacter } \\
\hline $\begin{array}{c}\text { netvericus" } \\
\text { NCTC } 12470^{T}\end{array}$ & 17 & \multirow{9}{*}{ Feline, faecal } & - & + & + & + & $C b-\mathrm{RI}$ \\
\hline NCTC 12471 & 1 & & - & + & + & + & $C b$-RVII \\
\hline NCTC 12472 & 1 & & - & + & + & + & $C b$-RIV \\
\hline NCTC 12473 & 1 & & - & + & + & + & $C b-\mathrm{RI}$ \\
\hline A722-91 & 1 & & - & + & + & + & $C b-\mathrm{RI}$ \\
\hline A723-91 & 1 & & - & + & + & + & $C b$-RI \\
\hline NCTC 12847 & 1 & & - & + & + & + & $C b-\mathrm{RVI}$ \\
\hline A $725-91$ & 1 & & - & + & + & + & $C b$-RI \\
\hline A727-91 & $1 J$ & & - & + & + & + & $C b-\mathrm{RI}$ \\
\hline E504-90 & 2 & Canine, faecal & - & + & + & + & $C b-\mathrm{RI}$ \\
\hline E1797-91 & 2 & \multirow{10}{*}{ Feline, faecal } & - & + & + & + & $C b-\mathrm{RI}$ \\
\hline NCTC 12845 & 2 & & - & + & + & + & $C h$-RII \\
\hline E1997-91 & 2 & & - & + & + & + & $C b$-RI \\
\hline E2018-91 & 2 & & - & + & + & + & $C b$-RII \\
\hline E2032-91 & 2 & & - & + & + & + & $C b-\mathrm{RI}$ \\
\hline NCTC 12848 & 2 & & - & + & + & + & $C b$-RVIII \\
\hline E2205-91 & 2 & & - & + & + & + & $C b-\mathrm{RI}$ \\
\hline E2220-91 & 2 & & - & + & + & + & $C b$-RI \\
\hline E2289-91 & 2 & & - & + & + & + & $C b-\mathrm{RI}$ \\
\hline E2388-91 & 2 & & - & + & + & + & $C b-\mathrm{RI}$ \\
\hline \multicolumn{8}{|l|}{$\begin{array}{c}\text { Campylobacter } \\
\text { upsaliensis }\end{array}$} \\
\hline NCTC $11541^{T}$ & 3 & Canine, faecal & + & - & + & - & $\mathrm{NT}$ \\
\hline \multicolumn{8}{|c|}{$\begin{array}{l}\text { 'C. upsaliensis- } \\
\text { like' strains } \dagger\end{array}$} \\
\hline C121-92 & 4 & Feline, faecal & - & + & + & + & $C b-\mathrm{RI}$ \\
\hline C123-92 & 4 & Canine, faecal & $+(w)$ & - & + & - & $\mathrm{NT}$ \\
\hline C126-92 & 4 & Canine, faecal & + & - & + & - & NT \\
\hline NCTC 12846 & 4 & Feline, faecal & - & + & + & + & $C b-\mathrm{RV}$ \\
\hline $\mathrm{C} 128-92$ & 4 & Feline, faecal & $+(w)$ & - & + & - & $\mathrm{NT}$ \\
\hline C129-92 & 4 & Canine, faecal & + & - & - & - & NT \\
\hline C130-92 & 47 & & - & + & + & + & $C b-\mathrm{RI}$ \\
\hline C131-92 & 4 & & + & - & + & - & $\mathrm{NT}$ \\
\hline C132-92 & 4 & & - & + & + & + & $C b-\mathrm{RI}$ \\
\hline C133-92 & 4 & & - & + & + & + & $C b-\mathrm{RI}$ \\
\hline C135-92 & 4 & & - & + & + & + & Ch-RI \\
\hline C136-92 & 4 & & $+(w)$ & - & + & - & NT \\
\hline C137-92 & 4 & & - & - & + & - & $\mathrm{NT}$ \\
\hline C138-92 & 4 & Feline, faecal & - & + & + & + & $C b$-RII \\
\hline NCTC 12849 & 4 & Femine, raecal & - & + & + & + & $C h$-RIX \\
\hline C140-92 & 4 & & - & + & + & + & $C b-\mathrm{RIII}$ \\
\hline C141-92 & 4 & & - & - & + & - & NT \\
\hline C142-92 & 4 & & + & - & + & - & NT \\
\hline C143-92 & 4 & & - & + & + & + & $C b-\mathrm{RI}$ \\
\hline C144-92 & 4 & & - & + & + & + & $C b$-RIII \\
\hline C145-92 & 4 & & $+(w)$ & - & + & - & NT \\
\hline NCTC 12838 & $4 J$ & & - & + & + & + & $C b$-RIII \\
\hline
\end{tabular}

(w), weak reaction; NT, not tested; superscript $\mathrm{T}$ denotes type strain.

* All the $C$. belveticus strains originated from Switzerland.

† All the ' $C$. upsaliensis-like' strains originated from the UK.

$\$ 1$, Stanley et al. (1992); 2, this report; 3, Sanstedt et al. (1983); 4, strains received from P. Griffith (University of Reading) as C. upsaliensis.

$₫ \mathrm{CHCU}$, band of $\sim 1260$ or $\sim 1410$ bp or two bands of $\sim 1260$ and $\sim 1410 \mathrm{bp}$.

$\| \mathrm{CH}$, band of $\sim 830$ or $\sim 960 \mathrm{bp}$, or two bands of $\sim 830$ and $\sim 960 \mathrm{bp}$. 
nucleotide sequence and potential secondary structure we have determined.

\section{METHODS}

Bacterial strains, culture conditions and phenotypic characterization. Campylobacter isolates and type strains used in this study are listed in Table 1 . They were cultured at $37^{\circ} \mathrm{C}$ on $5 \%$ $(\mathrm{v} / \mathrm{v})$ horse blood agar plates in a Variable Atmosphere Incubator (Don Whitley Scientific) which maintained a microaerobic atmosphere of (by vol.) $5 \% \mathrm{O}_{2}, 5 \% \mathrm{CO}_{2}, 2 \% \mathrm{H}_{2}$ and $88 \% \mathrm{~N}_{2}$. All strains were tested for catalase production, cytochrome oxidase production and nitrate reduction; and for selenite reduction, which differentiates $C$. belveticus from $C$. upsaliensis (Stanley et al., 1992).

Nucleic acid techniques. Preparation of genomic DNA, Southern blots, and filter hybridization were done as described previously (Stanley et al., 1992) except that the membrane filters were washed finally in $0.2 \times \mathrm{SSC}, 0.1 \% \mathrm{SDS}$ at $65^{\circ} \mathrm{C}$. Genomic dot-blots were prepared by vacuum-blotting of denatured genomic DNA $(5 \mu \mathrm{g})$ onto a Hybond-N nylon membrane filter (Amersham) using a Hybri-dot manifold (Bethesda Research Laboratories). Probe DNA was prepared from the recombinant plasmid pCH1 (Stanley et al., 1992) by excising the cloned $0.8 \mathrm{kbp}$ HindIII fragment from the vector pUC19 by standard methods (Sambrook et al., 1989) and labelling with biotin16-dUTP by random-priming.

DNA sequencing following PCR amplification of the $16 \mathrm{~S}$ rRNA genes (1500 bp and $1650 \mathrm{bp}$ respectively) of NCTC $12470^{\mathrm{T}}$ and NCTC 12838 was carried out as previously described (Staniey et al., 1992).

The PCR assay for C. belveticus and/or C. upsaliensis was made by subjecting $100 \mathrm{ng}$ genomic DNA (purified as above) to PCR in a final reaction volume of $100 \mu$ containing $10 \mathrm{mM}$ Tris $/ \mathrm{HCl}$ (pH 8.8); $200 \mu \mathrm{M}$ dNTPs; $0.4 \mu \mathrm{M}$ of each primer (see Results); $50 \mathrm{mM} \mathrm{KCl} ; 1.5 \mathrm{mM} \mathrm{MgCl}_{2} ; 0.1 \%$ Triton X-100 and 2.5 units of Taq XL DNA polymerase (Northumbria Biologicals). Samples were overlaid with $100 \mu$ light mineral oil (Sigma) and subjected to 25 cycles of amplification on a PCR heating block (Omnigene, Hybaid) with the following cycle conditions: denaturation $\left(94^{\circ} \mathrm{C}, 30 \mathrm{~s}\right)$; annealing $\left(50^{\circ} \mathrm{C}, 30 \mathrm{~s}\right)$; extension $\left(72{ }^{\circ} \mathrm{C}, 1 \mathrm{~min}\right)$. Amplicons were analysed by electrophoresis of a $10 \mu \mathrm{l}$ aliquot through a $1 \%(\mathrm{w} / \mathrm{v})$ agarose submarine gel.

A 550 bp probe for RFLP analysis at 16S rRNA gene loci was prepared as previously described for Helicobacter pylori (Linton $t$ al., 1992). Genomic DNA was digested with HindIII, for which there is no restriction site in the probe fragment.

Phylogenetic analysis of the 16S rRNA gene sequence of NCTC $12470^{\top}$. The $16 \mathrm{~S}$ rRNA sequence for the nominated typestrain was entered into 'RNA', a program for analysis of $16 \mathrm{~S}$ rRNA data written in Microsoft Quick BAsIC for use on IBM-PC compatible computers, and aligned as previously described (Paster \& Dewhirst, 1988). The reference database contained approximately 50 sequences of Campylobacter, Arcobacter, Helicobacter and Wolinella and 300 sequences of other Eubacteria. Similarity matrices were constructed from aligned sequences by using only those base positions for which $90 \%$ of the strains had data. The similarity matrices were corrected for multiple base changes (Jukes \& Cantor, 1969) and a phylogenetic tree was constructed by the neighbour-joining method (Saitou \& Nei, 1987). The reference strains with their GenBank accession numbers were those previously described for the phylogenetic analysis of $H$. canis (Stanley et al., 1993), except for C. jejuni subsp. doylei NCTC $11951^{\mathrm{T}}$ (accession number L14630),
Campylobacter sp. 'UPTC' NCTC 11845 (L14631), 'C. mucosalislike' strain CCUG 20705 (L14629), C. showae ATCC 51146' (L06974) and Campylobacter sp. PGC 40-6AT (L04318).

Secondary structure of the IVS found in NCTC 12838. Prediction of secondary structure of lowest free energy for the IVS was made according to the Zuker \& Stiegler (1981) algorithm in the DNASIS program.

\section{RESULTS}

\section{Preliminary characterization of the strain sets}

The first set comprised nine strains of $C$. belveticus including NCTC $12470^{\mathrm{T}}$ (Stanley et al., 1992). The second set (of Swiss origin) comprised ten strains which were identified by hybridization of culture-lysate dot blots (Burnens \& Nicolet, 1992) with DNA of NCTC $12470^{\mathrm{T}}$ : they included one canine (E504-90) and nine feline isolates. The third set (of UK origin) comprised three canine and nineteen feline isolates (see Table 1), received as C. upsaliensis from Dr P. Griffith, University of Reading, UK, and designated for the purposes of this study as ' $C$. upsaliensis-like'. The third set was used to evaluate a PCR identification assay for $C$. belveticus, and its discrimination from $C$. upsaliensis (see below). These 22 isolates were catalase-negative or weakly positive (' $\mathrm{CNW}$ '), oxidase positive and reduced nitrate.

\section{Nucleotide sequencing of the $16 \mathrm{~S}$ rrn gene of $C$. helveticus and design of species-specific PCR primers}

The DNA sequence of the gene from NCTC $12470^{\mathbf{T}}$ was determined, following PCR amplification of a fragment (nucleotides 7 to 1510 ), by using eight primers corresponding to phylogenetically-conserved regions (Stanley et al., 1993). The resulting sequence (GenBank accession number U03022) when compared with other eubacterial 16S rRNA sequences in our database, indicated that NCTC $12470^{\mathbf{T}}$ was a Campylobacter species closely related to $C$. upsaliensis. Comparisons were made at 1378 base positions, for which over $90 \%$ of the strains had data, and corrected for multiple base changes by the method of Jukes \& Cantor (1969). A phylogenetic tree obtained using the neighbour-joining method is shown in Fig. 1. There were three major clusters in the phylogenetic tree. The first cluster was composed of Campylobacter species and two generically misnamed Bacteroides species. The second cluster contained the four Arcobacter species. The third cluster consisted of Helicobacter species, 'Flexispira rappini' and Wolinella succinogenes.

The nearest neighbouring species to $C$. belveticus was $C$. upsaliensis ( $98.2 \%$ sequence similarity) and the new species was located in the cluster of thermotolerant Campylobacters, which includes $C$. jejuni subsp. jejuni $(97 \cdot 2 \%$ sequence similarity), C. jejuni subsp. doylei $(97 \cdot 1 \%$ sequence similarity) and $C$. coli ( $96.3 \%$ sequence similarity). The other Campylobacter species exhibited the following sequence similarities: C. lari (96.8\% similarity); C. fetus subsp. fetus $(93.1 \%$ similarity); C. byointestinalis $(93.5 \%$ similarity); C. mucosalis (92.5\% similarity); C. concisus $(92 \cdot 1 \%$ similarity); $C$. curvus $(91 \cdot 7 \%$ similarity); $C$. 


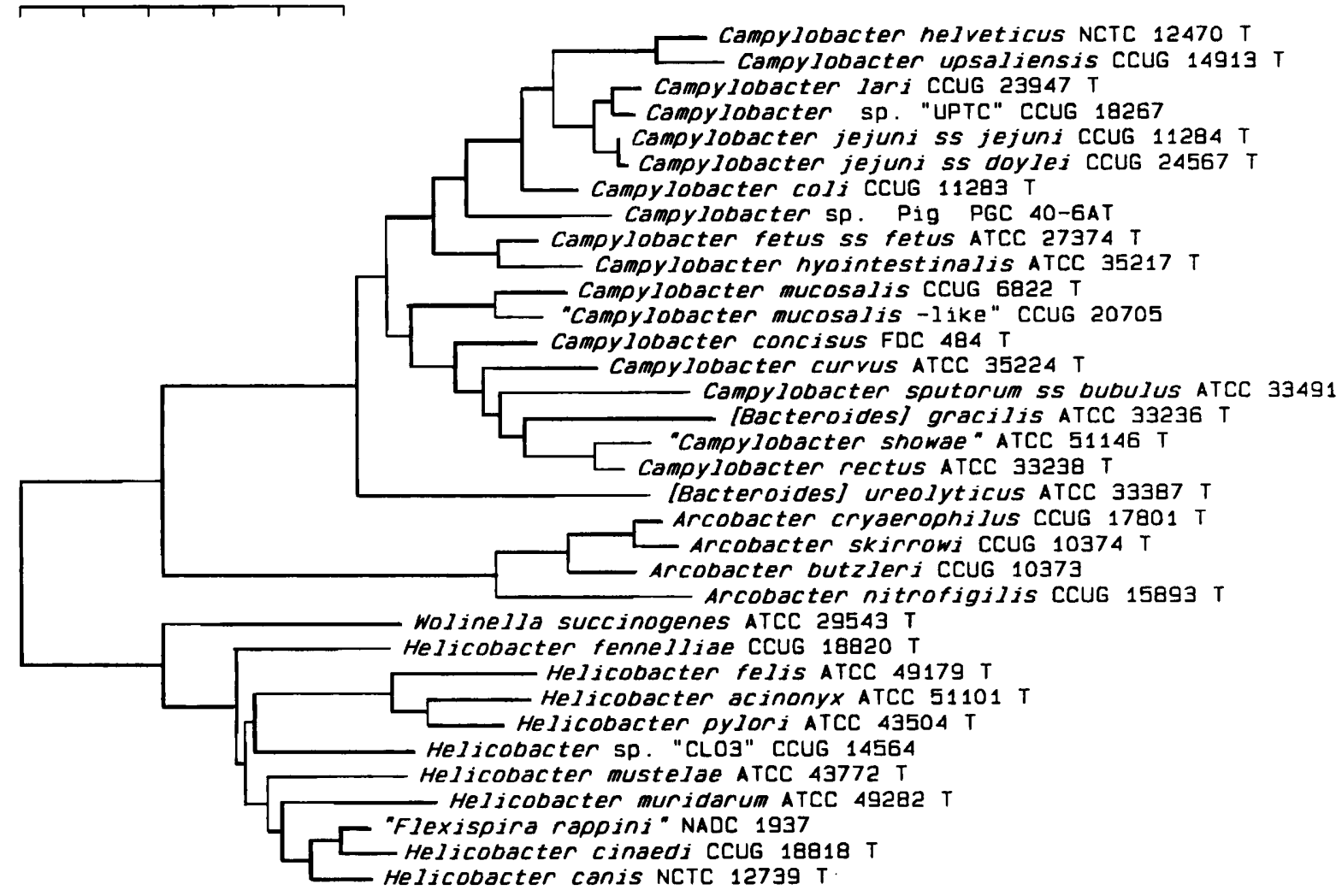

Fig. 1. Phylogenetic tree. C. helveticus and 33 reference species of Campylobacter, Arcobacter, Helicobacter and Wolinella were analysed by $16 \mathrm{~S}$ rRNA sequence similarity. The scale bar represents $5 \%$ difference in nucleotide sequence as determined by measuring the lengths of the horizontal lines connecting any two species. T, type strain.

sputorum subsp. bubulus ( $91.4 \%$ similarity); C. showae (91.2\% similarity) and $C$. rectus $(91.6 \%$ similarity). The Helicobacter species exhibited from $87.7 \%$ similarity $(H$. canis) to $85.3 \%$ similarity ( $H$. fennelliae).

The sequence was examined for unique regions which might act as priming sites for the species-specific amplification of a PCR product internal to the gerie. The oligomer 5'-CCC ATA CTC CTA TTT AGC AT-3', which is found at nucleotides 176 to 196 of the $C$. belveticus and $C$. upsaliensis sequences, was predicted as a suitable forward primer. The oligomer 5'-GAT TCC ACT GTG GGG GA-3', corresponding to nucleotides 1462 to 1478 of both species, was predicted as a reverse primer for a potential PCR product of $\sim 1260$ bp from these two, but not from any other Campylobacter species. If it was substituted by the oligomer $5^{\prime}$-ATA TCT CTA TAA GGT TCT TA-3' (nucleotides 991 to 1010 of the $C$. belveticus sequence) a PCR product of somewhat over 800 bp was predicted from $C$. belveticus alone.

\section{Rapid species-specific PCR identification of C. helveticus}

Amplification of species-specific PCR product(s) was compared with hybridization data obtained with a recombinant DNA probe, pCH1 (Stanley et al., 1992), by examining a set of ' $C$. upsaliensis-like' isolates (see above).
As shown in Fig. 2(a) and Table 1, pCH1 positively identified $12 / 22$ strains in this subset as $C$. belveticus. The remaining 10/22 strains and the $C$. upsaliensis control did not hybridize with $\mathrm{PCH} 1$. A parallel PCR experiment was carried out using the $C$. belveticus/C. upsaliensis primer pair (see above). A product of $\sim 1260$ bp was amplified from $16 / 22$ strains, a product of $\sim 1410$ bp was amplified from three strains, and products of both sizes were amplified from two strains (Fig. 2b). These were termed CHCU amplicons (Table 1). There was a single strain (C129-92) from which no CHCU product(s) were amplified and no products were amplified $\left(50^{\circ} \mathrm{C}\right.$ annealing temperature) from DNA of the type strains of $C$. jejuni (subsp. jejuni and doylei), C. coli, C. lari, C. byointestinalis, C. fetus (subsp. fetus and venerealis), C. mucosalis, C. concisus, C. sputorum (subsp. sputorum, faecalis and bubulus), C. curvus, $C$. rectus or any Helicobacter species. Therefore, the CHCU reaction was judged to be specific for C. upsaliensis/C. belveticus.

On the other hand, the primer pair designed for specificity to $C$. belveticus amplified products of $\sim 830 \mathrm{bp}$ and/or $\sim 980 \mathrm{bp}$ (termed $\mathrm{CH}$ products in Table 1). The annealing temperature for species-specific amplification of this $\mathrm{CH}$ product was determined to be $52^{\circ} \mathrm{C}$ - at this temperature, products were amplified from $C$. belveticus but not from any of the above-cited species of Campylobacter or Helicobacter. Those strains which had failed to reduce 

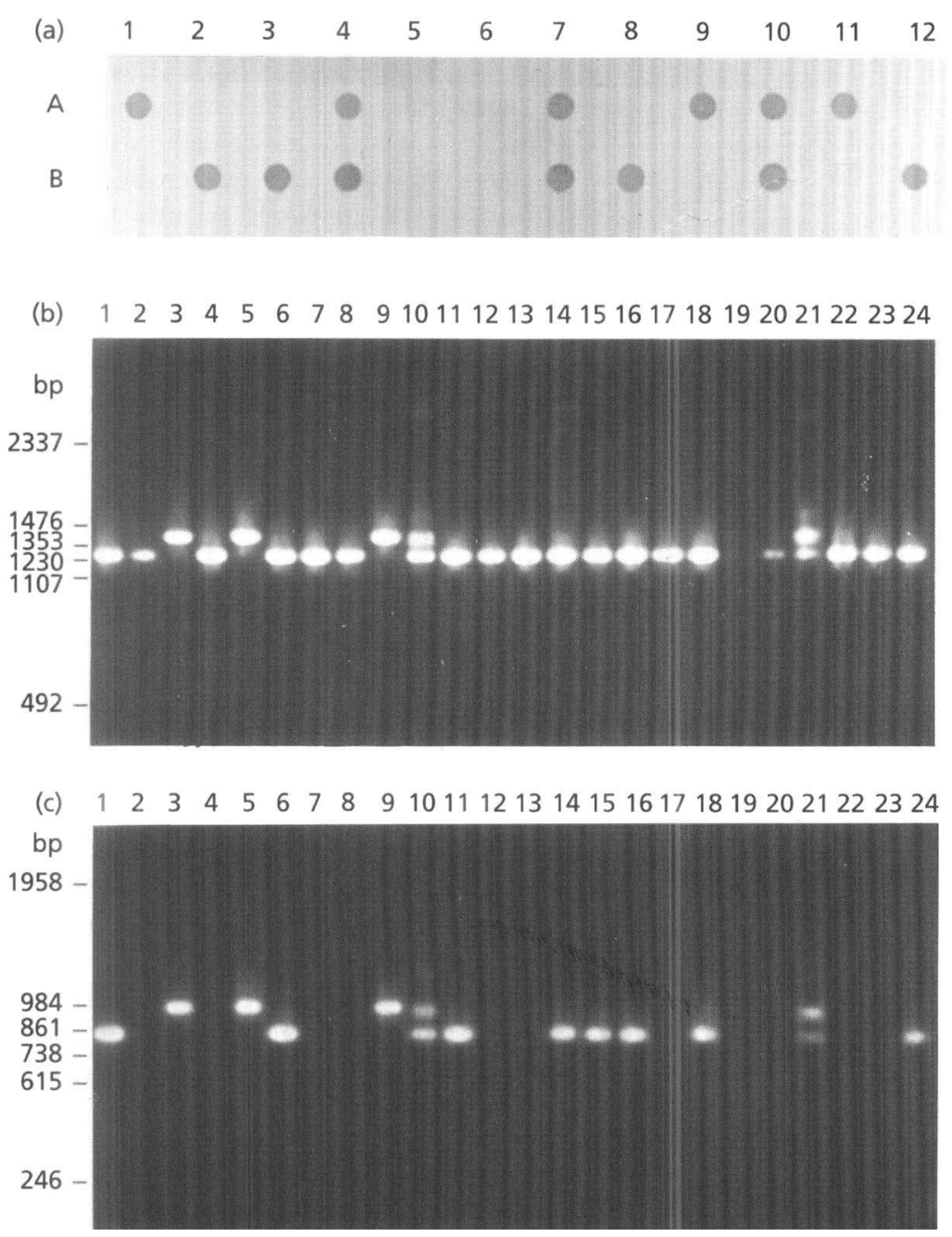

Fig. 2. (a) Rapid molecular identification of $C$. helveticus by DNA hybridization. Genomic dot-blot hybridized with probe $\mathrm{PCH}$. Position A1 contained DNA of strain C12192; position $A 2$ of strain C123-92; $A 3, C 126-$ 92; A4, NCTC 12846; A5, C128-92; A6, C12992; A7, C130-92; A8, C131-92; A9, C132-92; A10, C133-92; A11, C135-92; A12, C136-92; B1, C137-92; B2, C138-92; B3, NCTC 12849; B4, C140-92; B5, C141-92; B6, C142-92, B7, C143-92; B8, C144-92; B9, C145-92; B10, NCTC 12838; B11, C. upsaliensis NCTC $11541^{\top}$; B12, C. helveticus NCTC $12470^{\top}$. (b) PCR identification of $C$. helveticus and C. upsaliensis. The primer pair designed for specificity to both species amplified products of $1260 \mathrm{bp}, 1410 \mathrm{bp}$ or of both sizes. The order of strains on the $1 \%$ agarose gel is the inverse of that in (a), i.e. track 1 contained products from strain NCTC $12470^{\top}$; track 2 from NCTC 11541'; track 3, NCTC 12838; 4, C145-92; 5, C144-92; 6, C143-92; 7, C142-92; 8, C141-92; 9, C140-92; 10, NCTC 12849; 11 , C138-92; 12, C137-92; 13, C136-92; 14, C135-92; 15, C133-92; 16, C132-92; 17, C13192; 18, C130-92; 19, C129-92; 20, C128-92, 21, NCTC 12846; 22, C126-92; 23, C123-92; 24, C121-92. (c) PCR identification of $C$. helveticus. The primer pair designed for specificity to $C$. helveticus amplified products (termed $\mathrm{CH}$ ) of $830 \mathrm{bp}, 960 \mathrm{bp}$ or of both sizes. Order of strains as in (b).

selenite in preliminary phenotypic tests, and reacted with $\mathrm{pCH} 1$, produced $\mathrm{CH}$ amplification products. Amplicons of $\sim 830 \mathrm{bp}$ and $\sim 980 \mathrm{bp}$ occurring alone or in combination are shown in Fig. 2(c). Those strains from which the $\mathrm{CH}$ amplicon of $\sim 830 \mathrm{bp}$ was generated produced a CHCU amplicon of $\sim 1260 \mathrm{bp}$. Those strains from which a $\mathrm{CH}$ amplicon of $\sim 980 \mathrm{bp}$ was generated produced a CHCU amplicon of $\sim 1410 \mathrm{bp}$. Those strains from which both $\mathrm{CH}$ amplicons were generated produced both $\mathrm{CHCU}$ amplicons. Therefore $12 / 22$ isolates were definitively identified as $C$. belveticus. All strains in the first two sets were also verified as $C$. belveticus by $\mathrm{pCH} 1$ hybridization and the $\mathrm{CH}$ amplicon assay (data not shown).

\section{Molecular typing of C. helveticus by RFLP at $16 \mathrm{~S}$ rrn loci}

In order to estimate the copy number of the $16 \mathrm{~S}$ rRNA genes, and with a view to outlining a potential subtyping scheme for $C$. belveticus, restriction site variation was examined at the $16 \mathrm{~S} r \mathrm{rn}$ loci. Genomic Southern blots (HindIII digests) were probed with the 550 bp intragenic fragment, which has no HindIII site. Provided that hybridizing bands are sufficiently small to exclude the possibility that any one might carry closely-linked copies, the number of bands in a HindIII digest should correspond to the gene copy number. This analysis was made for the 20 strains of $C$. belveticus listed in Table 1 and for $12 C$. belveticus strains positively identified from the 'C. upsaliensis-like' set by $\mathrm{CH}$ amplicon production and positive $\mathrm{pCH} 1$ hybridization.

All strains exhibited homologous bands sized between $1 \cdot 7$ and $2.4 \mathrm{kbp}$. In $29 / 31$ strains three bands were detected, and in $2 / 31$ strains, two bands were observed, but comigrating fragments could not be excluded (Fig. 3, tracks 4 and 6 ). These results are consistent with a copy number of three in over $90 \%$ of the strains. Nine different $16 \mathrm{~S}$ rRNA gene profiles were found among the $C$. belveticus strains (Fig. 3). They were composed of combinations of seven homologous HindIII fragments, six of which $(1 \cdot 7$, $1 \cdot 85,2 \cdot 0,2 \cdot 1,2 \cdot 2$ and $2 \cdot 4 \mathrm{kbp}$ ) were present in more than one group of strains. The nine profiles occurred with varying frequency: one major and a number of minor subtypes were identified. The commonest profile (Fig. 3, track 10) was found in $18 / 31$ strains, the next most prevalent profiles (Fig. 3, tracks 9 and 8 ) in 3/31 strains and the rest in single strains only. 


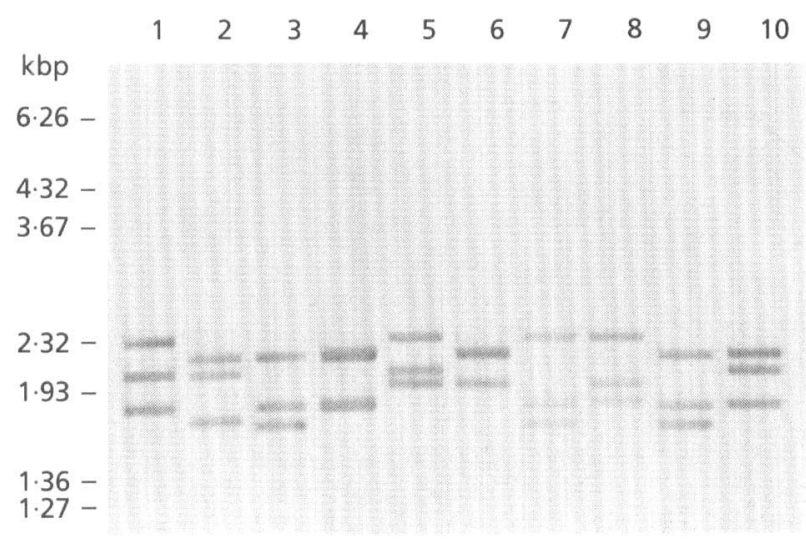

Fig. 3. $16 \mathrm{~S}$ rrn gene type profiles of C. helveticus. Genomic Southern blot made with HindIII-digested DNA hybridized with a $550 \mathrm{bp}$ internal fragment of the $16 \mathrm{~S} \mathrm{rrn}$ gene. Track 1 contained DNA of strain NCTC 12849; track 2, NCTC 12848; tracks 3 and 9, NCTC 12845; track 4, NCTC 12471; track 5, NCTC 12847; track 6, NCTC 12846; track 7, NCTC 12472; track 8, NCTC 12838. Track 10 contained DNA of NCTC $12470^{\top}$, exhibiting the most prevalent profile, termed RT I.

\section{Characterization of an IVS in the 16S rRNA gene of five strains}

Three of the isolates identified as C. belveticus in Fig. 2(c) produced an enlarged $\mathrm{CH}$ amplicon of $\sim 980 \mathrm{bp}$ as opposed to the amplicon of $\sim 830 \mathrm{bp}$ found in NCTC
$12470^{\mathrm{T}}$ (Fig. 2c, tracks 3, 5, 9 vs track 1). Two of the isolates produced $\mathrm{CH}$ amplicons of both sizes (Fig. 2c, tracks 10 and 21). The enlarged $16 \mathrm{~S}$ rRNA gene of strain NCTC 12838 (Fig. 2c, track 3) was subjected to sequence analysis (see Methods) and shown to differ from that of NCTC $12470^{\mathrm{T}}$ due to the presence of inserted DNA following nucleotide 210 . The sequence following this anomalous $148 \mathrm{bp}$ insert was identical to that found after nucleotide 212 of the NCTC $12470^{\mathbf{T}}$ sequence (data not shown). There was a single base pair deletion at position 211 of the conventional gene sequence. The $148 \mathrm{bp}$ intervening sequence (GenBank accession number U03021) contained no ORF, and when analysed for RNA secondary structure could be folded into a configuration with one major (nucleotides $4 / 22$ and $127 / 145$ ) and three minor stem-loops (Fig. 4). Examination of this sequence and its flanking regions revealed no signals for intron processing, and the insert was therefore designated an 'intervening sequence' or IVS.

In order to ascertain whether the enlargement of the gene in the other four strains was due to an IVS of similar size and location, primers corresponding to nucleotides $101-$ 120 (IVSF1) and 241-256 (IVSR2) of the 16S rRNA gene were employed for PCR analysis. Whilst an amplicon of $\sim 155 \mathrm{bp}$ was generated from NCTC $12470^{\mathrm{T}}$ as predicted (Fig. 5a, track 1), amplicons of $\sim 305$ bp were generated from NCTC 12838, C144-92 and C140-92 (Fig. 5a, tracks 2-4). Amplicons of both sizes were generated from the two strains previously predicted to have both classes of

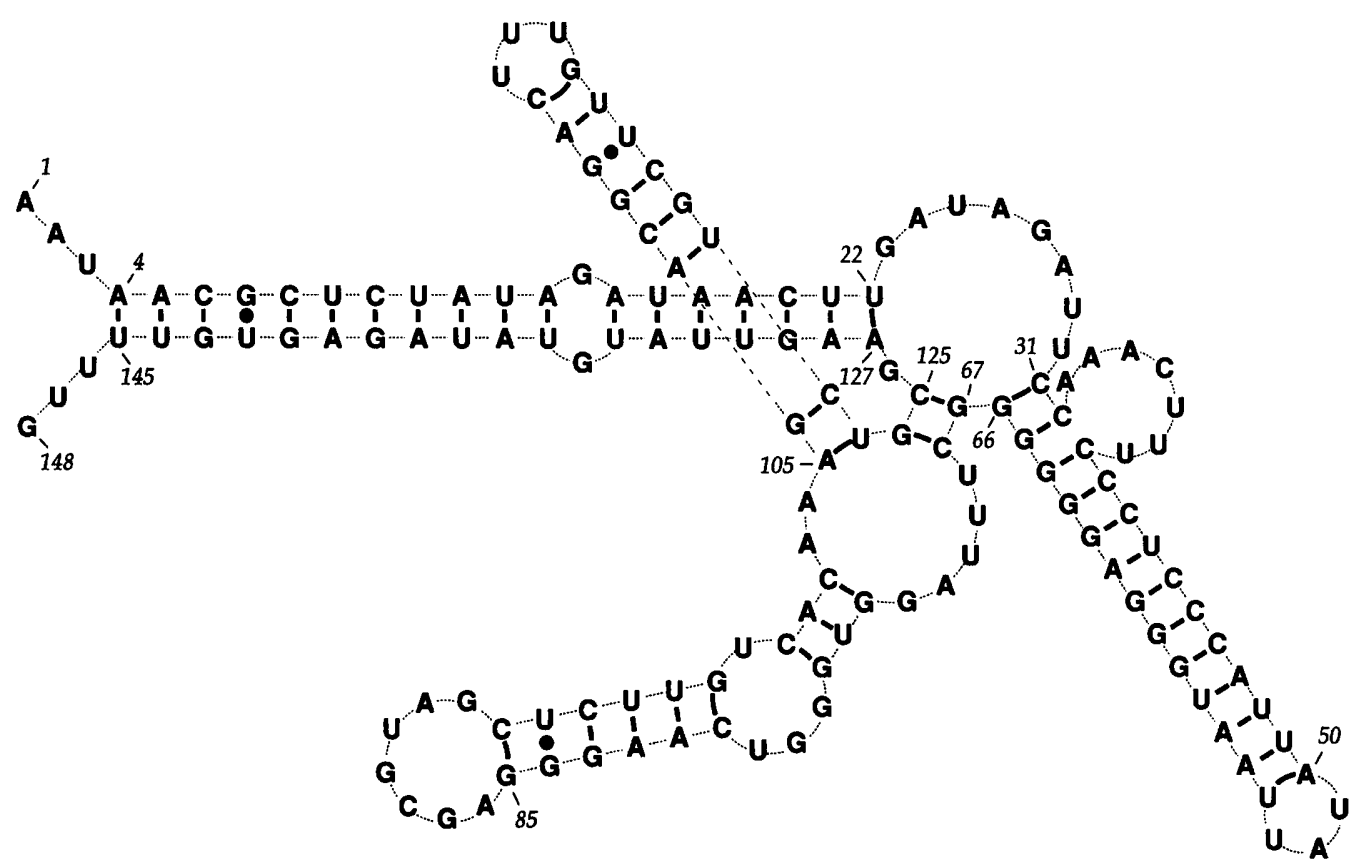

Fig. 4. Secondary structure of the 148 bp IVS found in the 165 rRNA gene of $C$. helveticus NCTC 12838. The RNA secondary structure, derived as described in Methods, was located at about nucleotide 210 of the gene, using the $E$. coli numbering system (Brosius et al., 1978). Solid lines denote hydrogen bonds, whilst single G-U hydrogen bonds are represented by 0 . The sugar-phosphate backbone is denoted by broken lines, and has been extended (for visual clarity) between nucleotides $106 / 107$ and $121 / 122$. 


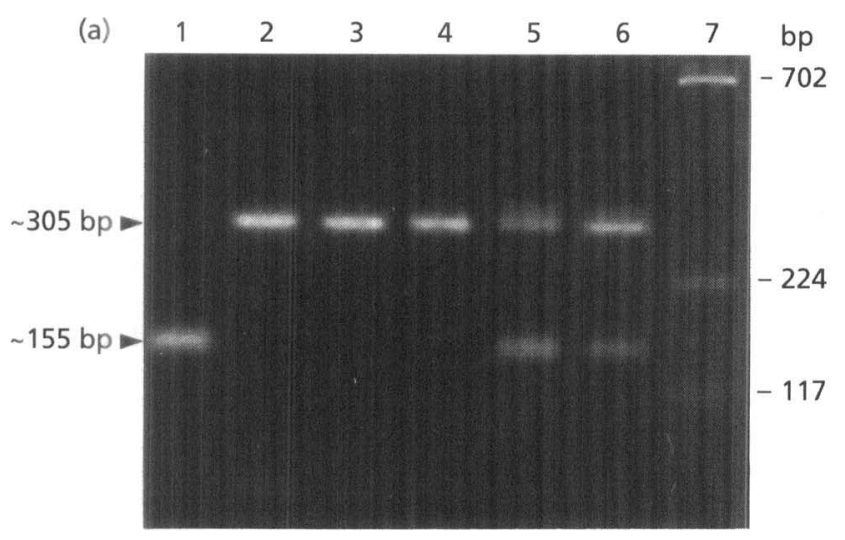

(b)
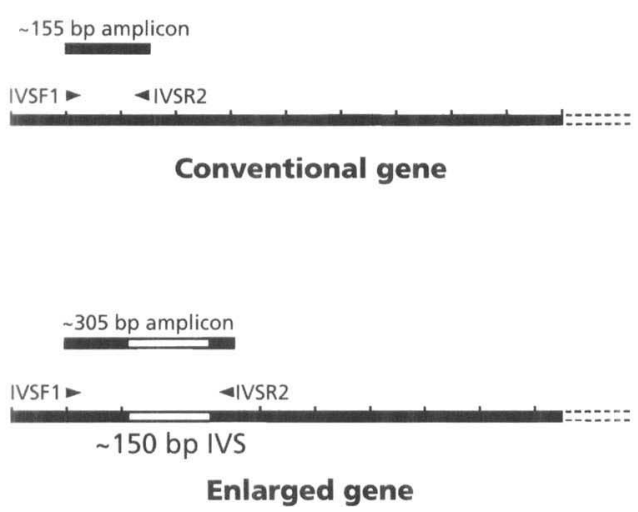

Fig. 5. PCR analysis of enlarged genes present in five strains of C. helveticus. (a) Agarose gel ( $1.5 \%)$ analysis of PCR amplicons generated with primer pair IVSF1 and IVSR2 from NCTC $12470^{\top}$ (track 1), NCTC 12838 (track 2), C144-92 (track 3), C140-92 (track 4), NCTC 12849 (track 5) and NCTC 12846 (track 6). BstEllgenerated fragments of phage $\lambda$ are shown as size markers in track 7. (b) Diagrammatic representation of the results. Scale marks represent $100 \mathrm{bp}$ intervals.

gene (Fig. 5a, tracks 5 and 6 vs Fig. 2c, tracks 10 and 21). These primers and amplicons are represented in Fig. 5(b). It was concluded that the five strains of $C$. belveticus concerned contain a $16 \mathrm{~S}$ rRNA gene enlarged by the presence of an IVS of similar size, located in the same region.

\section{DISCUSSION}

The $16 \mathrm{~S} r r n$ gene of $C$. belveticus NCTC $12470^{\mathrm{T}}$ exhibited $1.8 \%$ nucleotide sequence difference from that of $C$. upsaliensis and $2 \cdot 8-2.9 \%$ sequence difference from that of C. jejuni. The phylogenetic position so obtained (particularly the close relationship to $C$. upsaliensis, and the general placement among the thermotolerant species) agrees with previous results from the numerical analysis of cellular proteins, and from total DNA hybridization (Stanley et al., 1992). Therefore it is interesting to compare the biology of $C$. belveticus with that of C. upsaliensis. Both these Campylobacter species were first found in domestic pet animals: C. upsaliensis in dogs (Sanstedt et al., 1983) and cats (Fox et al., 1989) and C. belveticus in cats (Stanley et al., 1992) and rarely in dogs (this report). C. upsaliensis was subsequently shown to be a significant agent of human disease (Lastovica et al., 1989; Patton et al., 1989; Taylor et al., 1989; Goossens et al., 1990). The possible role of $C$. belveticus in human disease should therefore be examined, since it is sensitive to some selective media and conditions, and may also be easily misidentified as $C$. upsaliensis. For example, $45 \%$ of the third set of isolates of veterinary origin designated ' $C$. upsaliensis-like' by bacteriological criteria were shown by PCR and DNA probe identification to be $C$. belveticus strains. Isolates identified bacteriologically as $C$. upsaliensis should therefore be examined by the $\mathrm{CH}$ amplicon test.

We suggest that such methods are more definitive than conventional phenotypic tests for these biochemically inert microaerophilic Campylobacters. The availability of two species-specific PCR tests permits identification of $C$. belveticus - C. upsaliensis on the one hand, and differentiation of the two species on the other. Another advantage of PCR in this case is that positive identification is rapidly obtained from very little biological material. Clinical samples might be investigated in this way, removing the need for primary bacteriological isolation and cultivation, which is often difficult and time consuming for these species. Such rapid screening of clinical material could elucidate the carriage and disease association of $C$. belveticus in man. Although the $16 \mathrm{~S}$ rRNA sequence has previously been used for the design of species-specific oligonucleotide probes (Wesley et al., 1991), and primers for amplification of a $426 \mathrm{bp} \mathrm{PCR} \mathrm{product} \mathrm{from} C$. jejuni, $C$. coli and $C$. lari have also been described (Giesendorf $e t$ al., 1992), the primers described here yield the first specific PCR amplicons described for a single Campylobacter species.

Diverse probes have been employed to characterize polymorphism (RFLPs) at rRNA loci. They have included rRNA itself (Grimont \& Grimont, 1986), the cloned E. coli (5S-16S-23S) rrnB operon (Altwegg et al., 1989; Brosius et al., 1978) or an intragenic PCR-generated fragment of the 16S rrn gene alone (Linton et al., 1992). Better-defined probes permit conceptually simpler and accountable 'ribotyping' schemes to be developed. Results obtained here with a $550 \mathrm{bp}$ internal fragment of the $16 \mathrm{~S}$ rRNA gene are both simple and discriminatory. They indicated that the copy number of the gene in $C$. belveticus was generally three, in agreement with results previously obtained for C. jejuni and C. coli (Kim et al., 1992; Taylor et al., 1992). The nine profiles based on variation of HindIII sites in and around the $16 \mathrm{~S}$ tRNA gene of $C$. belveticus form the basis of a molecular typing scheme for the species, an approach which is also applicable to major agents of human disease such as $C$. jejuni. There was no association between the geographical origin of the isolates (Switzerland vs UK) and 16S rRNA gene profile. The most prevalent profile $(C b-\mathrm{RI})$ and a number of rarer or unique profiles were found among strains from either country.

The principal finding to emerge from this study is that 
certain strains of $C$. belveticus contain an IVS of $\sim 150 \mathrm{bp}$ in the 16S rRNA gene. This is a first report of the presence of inserted DNA in the phylogenetically important $16 \mathrm{~S}$ rRNA gene of a eubacterium. Only one exception to the uniform size of this gene has been described so far. This is in the archaeon Pyrobaculum aeropbilum (Burggraf et al., 1993), where an intron of 713 bp has been found in the gene. Intervening sequences (IVSs) of unknown function have however been demonstrated in the 23S rRNA gene, in the eubacteria Salmonella typhimurium, S. arizonae and Yersinia enterocolitica (Burgin et al., 1990; Skurnik \& Toivanen, 1991). The stem-loop structure of the $C$. belveticus IVS bears comparison with those found in the 23S rRNA gene of $S$. typhimurium and S. arizonae (Burgin et al., 1990), particularly with respect to the sequence and structure of the principal stem-loop. This region was shown to be the site of in vivo cleavage by RNaseIII, a processing enzyme which is thought to recognize secondary structural features of duplex stems rather than simple nucleotide sequences. This would be consistent with excision of the $148 \mathrm{bp}$ IVS during maturation of $16 \mathrm{~S}$ rRNA in these $C$. belveticus strains. As to the occurrence of strains (genes) of $C$. belveticus with and without the IVS, the question arises whether the enlarged 16S rRNA gene represents an ancestral state, or whether it is 'recently' acquired in some strains (genes) by recombination or rearrangement. These questions can only be resolved by further studies of $C$. belveticus and related species containing similar $16 \mathrm{~S}$ rRNA gene insertions.

At the time of writing, similarly enlarged genes have been detected in certain other eubacterial species belonging to the genera Campylobacter and Helicobacter. The sequences, structures and significance of these insertions will be reported elsewhere.

\section{ACKNOWLEDGEMENTS}

We thank Pippa Griffith (University of Reading) for the gift of strains here designated as ' $C$. upsaliensis-like', Pauline Borman for culture and maintenance of Campylobacter strains, Bruce Paster for assistance with sequence analysis and Jon White for computer-generated artwork.

\section{NOTE ADDED IN PROOF}

While this paper was in press, a paper by Van Camp et al. (Sy.st Appl Microbiol 16, 361-368, 1993) was published, in which an insert in the $16 \mathrm{~S}$ rRNA gene of Campylobacter sputorum was reported.

\section{REFERENCES}

Altwegg, M., Hickman-Brenner, F. W. \& Farmer, J. J. I. (1989). Ribosomal RNA gene restriction patterns provide increased sensitivity for typing Salmonella typhi strains. J Infect Dis 160, 145-149.

Brosius, J., Palmer, M. L., Kennedy, P. J. \& Noller, H. F. (1978). Complete nucleotide sequence of a 16S ribosomal RNA gene from Escherichia coli. Proc Natl Acad Sci US A 75, 4801-4805.

Burggraf, S., Larsen, N., Woese, C. R. \& Stetter, K. O. (1993). An intron within the $16 \mathrm{~S}$ ribosomal RNA gene of the archaeon Pyrobaculum aerophilum. Proc Natl Acad Sci US A 90, 2547-2550.
Burgin, A. B., Parodos, K., Lane, D. J. \& Pace, N. R. (1990). The excision of intervening sequences from Salmonella $23 \mathrm{~S}$ ribosomal RNA. Cell 60, 405-414.

Burnens, A. P. \& Nicolet, J. (1992). Detection of Campylobacter upsaliensis in diarrheic dogs and cats, using a selective medium with cefoperazone. Am J Vet Res 53, 48-51.

Fox, J. G., Maxwell, K. O., Taylor, N. S., Runsick, C. D., Edmonds, P. \& Brenner, D. J. (1989). "Campylobacter upsaliensis" isolated from cats as identified by DNA relatedness and biochemical features. $J$ Clin Microbiol 10, 2376-2378.

Giesendorf, B. A. J., Quint, W. G. V., Henkens, M. H. C., Stegeman, H., Huf, F. A. \& Niesters, H. G. M. (1992). Rapid and sensitive detection of Campylobacter spp. in chicken products by using the polymerase chain reaction. Appl Environ Microbiol 58, 3804-3808.

Goossens, G., Vlaes, L., de Boeck, M., Pot, B., Kersters, K., Levy, J., de Mol, P., Butzler, J.-P. \& Vandamme, P. (1990). Is "Campylobacter upsaliensis" an unrecognised cause of human diarrhoea? Lancet 335, 584-586.

Grimont, F. \& Grimont, P. A. D. (1986). Ribosomal ribonucleic acid gene restriction patterns as potential taxonomic tools. Ann Inst Pasteur Microbiol 137B, 165-175.

Jukes, T. H. \& Cantor, C. R. (1969). Evolution of protein molecules. In Mammalian Protein Metabolism, vol. 3, pp. 21-132. Edited by H. N. Munro. New York: Academic Press.

Kim, N. W., Bingham, H., Khawaja, R., Louie, H., Hani, E., Neote, K. \& Chan, V.L. (1992). Physical map of Campylobacter jejuni TGH9011 and localization of 10 genetic markers by use of pulsedfield gel electrophoresis. J Bacteriol 174, 3494-3498.

Lastovica, A. J., le Roux, E. \& Penner, J. L. (1989). “Campylobacter upsaliensis" isolated from blood cultures of pediatric patients. J Clin Microbiol 27, 657-659.

Linton, D., Moreno, M., Owen, R. J. \& Stanley, J. (1992). 16S rrn gene copy number in Helicobacter pylori and its application to molecular typing. J Appl Bacteriol 73, 501-506.

Paster, B. J. \& Dewhirst, F. E. (1988). Phylogeny of Campylobacters, Wolinellas, Bacteroides gracilis, and Bacteroides ureolyticus by $16 \mathrm{~S}$ ribosomal ribonucleic acid sequencing. Int J Syst Bacteriol 38, 56-62.

Patton, C. M., Shaffer, N., Edmonds, P., Barret, T. J., Lambert, M. A., Perlman, D. M. \& Brenner, D. J. (1989). Human disease associated with "Campylobacter upsaliensis" (catalase-negative or weakly positive Campylobacter species) in the United States. J Clin Microbiol 27, 66-73.

Saitou, N. \& Nei, M. (1987). The neighbour-joining method: a new method for reconstructing phylogenetic trees. Mol Biol Evol 4, 406-425.

Sambrook, J., Fritsch, E. F. \& Maniatis, T. (1989). Molecular Cloning, a Laboratory Manual, 2nd edn. Cold Spring Harbor, NY: Cold Spring Harbor Laboratory Press.

Sanstedt, K., Ursing, J. \& Walder, M. (1983). Thermotolerant Campylobacter with no or weak catalase activity isolated from dogs. Curr Microbiol 8, 209-213.

Skurnik, M. \& Toivanen, P. (1991). Intervening sequences (IVSs) in the $23 S$ ribosomal RNA genes of pathogenic Yersinia enterocolitica strains. The IVSs in Y. enterocolitica and Salmonella typhimurium have a common origin. Mol Microbiol 5, 585-593.

Stanley, J., Burnens, A. P., Linton, D., On, S. L. W., Costas, M. \& Owen, R. J. (1992). Campylobacter belveticus sp. nov., a new thermophilic species from domestic animals: characterization and cloning of a species-specific DNA probe. $J$ Gen Microbiol 138, 2293-2303.

Stanley, J., Linton, D., Burnens, A. P., Dewhirst, F. E., Owen, R. J., 
Porter, A., On, S. L. W. \& Costas, M. (1993). Helicobacter canis sp. nov., a new species from dogs: an integrated study of phenotype and genotype. J Gen Microbiol 139, 2495-2504.

Taylor, D., Hiratsuka, K. \& Mueller, L. (1989). Isolation and characterization of catalase-negative and catalase-weak strains of Campylobacter species, including "Campylobacter upsaliensis", from humans with gastroenteritis. J Clin Microbiol 27, 2042-2045.

Taylor, D. E., Eaton, M., Yan, W. \& Chang, N. (1992). Genome maps of Campylobacter jejuni and Campylobacter coli. J Bacteriol 174, 2332-2337.

Wesley, I. V., Wesley, R. D., Cardella, M., Dewhirst, F. E. \& Paster,
B. J. (1991). Oligodeoxynucleotide probes for Campylobacter fetus and Campylobacter byointestinalis based on 16S rRNA sequences. $J$ Clin Microbiol 29, 1812-1817.

Woese, C. R. (1987). Bacterial evolution. Microbiol Rev 51, 221-271. Zuker, M. \& Stiegler, P. (1981). Optimal computer folding of large RNA sequences using thermodynamics and auxiliary information. Nucleic Acids Res 9, 133-148.

Received 22 July 1993; revised 23 September 1993; accepted 11 October 1993. 